\title{
Primatology
}

\section{The Good, The Bad and The Ugly: Perceptions of Wildlife In Tombali (Guinea-Bissau, West Africa)}

\author{
Susana Costa ${ }^{1,2 *}$, Catarina Casanova ${ }^{2}$, Claudia Sousa $^{3}$ and Phyllis Lee ${ }^{1}$ \\ ${ }^{1}$ School of Natural Sciences, Division of Psychology, University of Stirling, Stirling, FK9 4LA, Scotland \\ ${ }^{2}$ CAPP: Centro de Administracao e Politicas Publicas and Instituto Superior de Ciencias Sociais e Políticas da Universidade Tecnica de Lisboa, Rua Almerindo Lessa, \\ Polo Universitario do Alto da Ajuda, 1349-055 Lisboa, Portugal \\ ${ }^{3}$ CRIA - Centre for the Research in Anthropology and Departament of Anthropology, Faculdade de Ciencias Sociais e Humanas, Universidade Nova de Lisboa, Av de \\ Berna, 26-C, 1069-061 Lisboa, Portugal
}

\section{Introduction}

Understanding how people perceive of and relate to their natural environments is vital to conservation action. Perceptions can be harnessed for positive conservation engagement, even when associated with personal costs [1-3]. Negative perceptions provide information about gendered power, exclusion from social capital, and lack of engagement or compliance with natural resource preservation [2-5]. Conservation practitioners have long recognized the need to work closely with local communities, both for promoting sustainable development and alternative livelihoods (Integrated Conservation with Development or ICDP; $[2,4,6,7]$ and for generating positive responses towards conservation practices. One problem with such aims is that an effective conservation program must understand and potentially be able to incorporate local values with respect to the resources being conserved, rather than focusing on the benefits as the conservation practitioner perceives them.

A mismatch between conservation initiatives and local perceptions of species of conservation concern and actions for their protection has been found for a variety of species (e.g. elephants-[8]; red colobus[9]; baboons-[10]). In addition, conservation tends to be viewed positively by local communities when benefits accrue at the individual level and negatively when benefits are societal or externalized [1,2]. Environmental actors cannot therefore make assumptions about shared core values or the willingness to accept costs resulting from biodiversity protection. Beliefs and perceptions which may conflict with conservation outcomes need to be explored prior to program implementation.

Western scientific conservation models and expectations are often challenged in the context of African non-equilibrium ecosystems; furthermore lack of a practical ability to implement existing legislative protection, such as restrictions on hunting or logging, tends to result in uncontrolled threats to biodiversity [11]. Hunting, the bushmeat trade and bushmeat consumption are major threats to the continued existence of some species, specifically primates and other slowlyreproducing animals (see for example [12-18]. As such, in an area where protection from hunting has been legislated but has yet to be effectively enforced, as in the Cantanhez National Park (Tombali, Guinea-Bissau, West Africa), a detailed understanding of sociozoologic traits (biophilic, utilitarian, authoritarian, scientific; [19] attributed to species of conservation concern should aid in developing locally effective conservation actions.

Whether people in a local community actually share core values or beliefs about animals or the natural world has only infrequently been examined in the context of conservation. Individual perceptions of wildlife are composed of at least two different factors: (i) the individual's cognitive constructs and (ii) the cultural context where s/ he was raised. This second factor is a function of the values, norms, beliefs (eg. religion) and attitudes that operate in the society where the subject resides [20]. To be accepted, one has to internalize and exhibit such features [21]. Socialization allows for organized perceptions which thus acquire meaning and significance with respect to the patterns and expectations of one's culture [21-26]. People internalize positions relative to other humans, wildlife and the ecosystem $[27,28]$. Understanding the nature of such perceptions is vital when attempting to translate conservation priorities into locally supported action $[29,30]$. The variety of perceptions about other living organisms takes on a special meaning in Africa, where genders, different ethnicities, and religions co-exist in the same localities and share (or contest) the same resources. Such mixing is the case of the Tombali region of the Republic of Guinea-Bissau where often people from different cultural backgrounds and contexts share the same "tabanca" (village) [31]. The homogenous treatment of communities in a conservation context has failed to capture the differential access to resources or benefits for some clusters of a local population, which seems to be specifically the case for women, children and the poor [32,33].

Cantanhez National Park was established in 2007 to protect remnant forests containing unique Guinean biodiversity, but the park only exists theoretically [7] as it is not yet effectively protected. In this 105,700 ha area, 20,000 people from six ethnic communities co-exist in 110 villages. The Nalú people-representing $10 \%$ of the population living in Tombali is traditionally considered the "owners of the ground" [34-37], while the Balanta people are the most numerous ethnic group (62\%). Nalú people traditionally have their own mechanisms for forest protection, using a rudimentary zoning strategy [38], and are animists or recent Muslim converts. The Balanta tend to be Chatholic.

A key threatened species in the Park is the western chimpanzee (Pan t. verus). We know little about the size of the chimpanzee population living inside the Guinean territory; they were declared extinct in 1988 [39-41], and only when Gippoliti and Dell'Omo (1996) conducted a survey along the River Corubal and in the Cantanhez forest was a population rediscovered. Data from nest counts and surveys suggest that chimpanzees in Guinea-Bissau number from 600 to 1000 [41] Chimpanzees are apparently more common in Cantanhez National Park than elsewhere in the country [41]. Along with chimpanzees

*Corresponding author: Susana Costa, School of Natural Sciences, Division of Psychology, University of Stirling, Stirling, FK9 4LA, Scotland, Tel: +351213619430; Fax: +351213619442; E-mail: susanagkosta@gmail.com

Received February 12, 2013; Accepted March 18, 2013; Published March 21, 2013

Citation: Costa S, Casanova C, Sousa C, Lee P (2013) The Good, The Bad and The Ugly: Perceptions of Wildlife In Tombali (Guinea-Bissau, West Africa). J Primatol 2: 110. doi:10.4172/2167-6801.1000110

Copyright: () 2013 Costa S, et al. This is an open-access article distributed under the terms of the Creative Commons Attribution License, which permits unrestricted use, distribution, and reproduction in any medium, provided the original author and source are credited. 
are at least 9 other primate species: the threatened Guinea baboon (Papio papio), red colobus (Procolobus badius temminckii), puttynosed monkey (Cercopithecus nictitans), lesser spot-nosed monkey (Cercopithecus (c.) petaurista), green monkey (Chlorocebus sabaeus), black and white colobus (Colobus polykomus), Mona monkey (Cercopithecus (m.) campbelli), Sooty mangabey (Cercocebus atys), and the bush baby (Galago spp. senegalensis). All primates except the chimpanzees are actively hunted and traded as bushmeat.

In developed economies, peoples' perceptions may organize the animal kingdom symbolically into "good" and "bad" animals [27]. While phylogeny classifies animals according to biological features and affinities, the sociozoologic scale organizes species as a function of their perceived or actual roles played in the local society. "Good" animals, for instance, have a high moral status due to their subordinate roles. They accept their status and reinforce the concept that humans are the pinnacle of the animal kingdom. Companion animals, livestock and lab animals are examples of nonhumans perceived as "decent citizens". On the other hand, "bad" animals are viewed as uncontrolled creatures capable of subverting the sociozoologic scale. "These animals do not fear humans, humans fear them. These animals hunt humans, humans do not hunt them. These animals have power over humans; humans do not have power over them".

Wildlife such as snakes, sharks and wolves are seen as "bad" animals due to their untamed and/or dangerous behaviour. Although such constructs are typically shared by the majority of individuals, the scales are sufficiently flexible to allow "good" animals, for example "dangerous" dogs, to turn "bad" [42-45]. These terms may also access a basic biophilic approach to nature [19], and thus distinguish the "useful" from those appreciated for other values. Using Arluke and Sanders' model (1996) as a basis, we established a "preference ranking" in order to determine which wildlife species people from Tombali region like and/or dislike the most and assess the factors which underlie these preferences $[46,47]$. In addition we consider how these features are correlated with each other.

This research is part of a larger project that aims to protect remnant patches of tropical rainforest and their resident populations of threatened chimpanzees (Pan troglodytes verus), via a communitybased conservation approach $[29,30]$. Conservation projects can attract greater local and international support when an appropriate flagship species is chosen as a project symbol, as flagship species are attractive and charismatic to the public [7,48-50]. Since the larger project addresses the persistence of the highly threatened chimpanzees in relict forest fragments, here we focus on how the local population perceives chimpanzees in order to assess perceptual biases and threats towards their continued existence, and to understand if they are an appropriate flagship species for the larger project.

Three hypotheses were considered: (i) A correlation between positive attitudes and edibility was expected for most species, except for chimpanzees that may hold attributes other than those of utility; (ii) Chimpanzees were expected to be perceived as "similar to humans", due to their appearance, which should produce positive perceptions; (iii) Perceptions will reflect gender and religious differences. Women, who are disempowered and gain few benefits from conservation programs (see for example: [43-47]) and who contact chimpanzees during crop-raiding may dislike and fear chimpanzees more than men, making this species problematic as a flagship species. In addition, religion was expected to influence the degree of anthropocentrism, such that Muslims may be more anthropocentric that non-Muslims and thus value species differently.

\section{Materials and Methods}

Field work took place in Tombali, a patchy tropical rainforest area in the south of Guinea-Bissau (lat: $11^{0} 16^{\prime} 42.78^{\prime \prime} \mathrm{N}$; long: $14^{0} 54^{\prime} 42.30^{\prime \prime} \mathrm{W}$ ). A questionnaire-based survey, using mainly fixed response or closed questions was conducted over a two month period (February and March 2007). The limited period was intentionally designed to limit fluctuations in negative or positive responses due to seasonal humanwildlife conflict (crop raiding etc; [50]).

In order to establish the sociozoologic scale for the people from Tombali, we showed pictures $(\mathrm{N}=27)$ of the Guinean fauna to the subjects (Table 1). In order to assess the accuracy and veracity of respondents, a picture of a capuchin monkey (Cebus capuchinus) was added-a primate species found only in South America. Then, we asked the participants to identify the top three animals that they considered

\begin{tabular}{|c|c|c|}
\hline Common name & Scientific name & Creole name \\
\hline \multicolumn{3}{|l|}{ Primates } \\
\hline Chimpanzee & Pan troglodytes verus & Dári \\
\hline Black and white colobus & Colobus polykomus & Sancho fidalgo \\
\hline Red colobus & Procolobus badius temminckii & Fatango \\
\hline Mona monkey & Cercopithecus (m.) campbelli & Sancho mona \\
\hline Baboon & Papio (h.) papio & Kón \\
\hline Patas monkey & Erythrocebus patas & Sancho fula \\
\hline Sooty mangabey & Cercocebus atys & Sancho \\
\hline Grivet monkey / Vervet & $\begin{array}{l}\text { Cercopithecus (Chlorocebus) } \\
\text { (a.) sabaeus }\end{array}$ & Sancho tarrafe \\
\hline Bush baby & Galago senegalensis & Sancho \\
\hline Putty-nosed monkey & Cercopithecus nictitans & Sancho \\
\hline $\begin{array}{l}\text { Lesser spot-nosed } \\
\text { monkey }\end{array}$ & Cercopithecus (c.) petaurista & Sancho \\
\hline $\begin{array}{l}\text { Capuchin monkey } \\
\text { (Amazonia) }\end{array}$ & Cebus capuscinus & Sancho \\
\hline \multicolumn{3}{|l|}{ Other wild mammals } \\
\hline Roan antelope & Kobus ellipsiprymus unctuosus & $\begin{array}{l}\text { Sim-sim or boca- } \\
\text { branca }\end{array}$ \\
\hline Gazelle & Gazella gazella & Gazela \\
\hline Pangolin & Manis tetradactyla & Tucurtacars \\
\hline Hyena & Crocuta crocuta & Lobo \\
\hline \multicolumn{3}{|l|}{ Birds } \\
\hline Purple glossy starling & Lamprotornis purpureus & Cacho \\
\hline $\begin{array}{l}\text { Abyssinian ground- } \\
\text { hornbill }\end{array}$ & Bucorvus abyssinicus & Cacho \\
\hline \multicolumn{3}{|l|}{ Fish } \\
\hline Mudskipper & Periophthalmus argentilineatus & Saltón \\
\hline \multicolumn{3}{|l|}{ Reptiles } \\
\hline Snake & Pyton sebae & Irancego \\
\hline Turtle & Kinixys belliana nogueyi & Tartaruga \\
\hline \multicolumn{3}{|l|}{ Insects } \\
\hline Butterfly & Brephidium species & Borboleta \\
\hline African honey bee & Apis mellifera scutellata & Baguera \\
\hline \multicolumn{3}{|l|}{ Domestic animals } \\
\hline Pig & Sus scrofa scrofa & Porco \\
\hline Chicken & Gallus gallus domesticus & Galinha \\
\hline Cow & Bos primigenius & Baca \\
\hline Goat & Capra aegagrus hircus & Cabra \\
\hline
\end{tabular}

Table 1: Animal species presented in the photos for rating. All the photos were coloured and about the same size in order to avoid the influence of subjective variables in subjects' choices. Photos were identified with Roman numbers to enable the subsequent coding of photos sequentially for analysis, without attributing familiar numerical values to photos, and thus avoiding the assumption that a certain photo number 1 would be better than another one numbered 20 . Photo order of presentation was randomized or mixed between each presentation. 
to hold the qualities of "good", "bad", "pretty", "ugly", "edible", "inedible", "intelligent", "unintelligent", "often seen", "less seen" and "similar to humans". They were asked to identify these three species in order of importance to them. People chose specific photos of animals to represent specific adjective or qualities. For each of the three species that were, for example, chosen as "good", the first chosen animal was given a score of 3 for that individual, and so on for each of the three choices. The assumption was that first chosen species represented the most salient or immediate representative of that quality [51]. If not mentioned in the context of any quality, the species was assigned a 0 for that participant. These values were then allocated to each available species across all 257 participants. Quality associated with each species by respondent was used as an independent variable, and values thus varied from 0 to 3 . The total number of times that subjects pinpointed certain animals was, in itself, a signal of their importance in the Tombali sociozoologic scale. We anticipated that it would be difficult to fully understand the underlying reasons why certain animals were perceived as "good" or "bad". For this reason, Principal Component Analysis (PCA) was done to explore associations between perceptions; firstly to identify correlations between perceptions and then to distinguish clusters of similar perspectives across the subjects [52,53]. Respondent ID or other associated individual variables such as gender and ethnicity were not used in the PCA analysis due to reduction in the sample size below that required for PCA. Of all the 27 pictures shown to 257 people, only these four categories of animals (i.e., chimpanzees, baboons, gazelles and hyenas) were rated consistently enough to be able to enter them into the PCA analysis. PCA was run in SPSS versions 14-17 with and without varimax rotation. The initial correlation matrix between variables was examined to ensure that there were associations worth investigating. The factors retained for all animals were those that had eigenvalues greater than 1 , especially relevant when the sample size exceeds 250 as in our study. We retained all component loadings greater than 0.364 [52].

Finally, we asked the subjects to tell us which animal in the photos they would choose to be if they could no longer be human and which they would least like to be. The aim of these last two questions was to confirm the sociozoologic status of the previously ranked species and to explore the variables "religion" and "gender" as potential influences on perceptions of wildlife. Associations between these variables and the rankings of animals that people would/would not like to be if they could not be human were assessed using Chi-square and Cramer's V tests. Level of education (generally non-existent) and socio-economic status (non-differentiated) were not examined here as variance was too low for these factors to be useful. Analyses were made using SPSS V17, with probability at $<0.05$, two tailed.

Our sample included all adults in the region who could be contacted and orally expressed a willingness to participate. Due to a lack of reliable census information, the sample was non-probabilistic [54], while keeping two variables-gender $($ male $=133 /$ female $=124)$ and religion (Muslim: $n=139 /$ non-Muslin $n=118$ )-as balanced as possible. While we tried to match age categories, in this cultural context a subject's age was not always easy to access. Many people did not have identification documents or know their date of birth. This was especially true for women who had never attended school. Even when subjects reported their age, the information was not always reliable. Thus, we had to rely on our perception of respondents' apparent age to classify them as (i) young adult $(<20 ; n=79)$, (ii) mid-adult $(20-39 ; n=82)$ and (iii) older adult $(40+; n=71)$. A total of 25 had no age attribution.

Participants were interviewed individually and on a face-to- face basis. Potential participants were approached verbally and, after agreeing to collaborate in the research with the freedom to stop at any time, they were asked to examine the photos. Written consent for participation was not possible given the non-literate nature of many participants. Questions were asked in Portuguese, the official language of Guinea-Bissau, and translated directly into Creole by an interpreter. Back translations [55] were made in order to validate translations. The answers, due to their simplicity, were written directly into the survey form. No voice recorder or other similar devices were used.

\section{Results}

\section{Principal components of traits for each species}

For the four species examined, the PCA appeared robust and applicable.

For chimpanzees, component 1 was consistent with positive attitudes (Table 2). The second component consisted of people who mentioned frequent encounters with chimpanzees. However, the attribute "bad" was negatively correlated with "often seen" for chimpanzees. As such respondents in this cluster also had non-negative attitudes toward chimpanzees. The third component included people that ranked chimpanzees highly as "inedible", "similar to people" and "ugly". The fourth cluster did not clearly distinguish perceptions. Nevertheless, this component might be associated with negative attitudes, since "good" and "pretty" were negatively correlated with "ugly".

Perceptions regarding baboons were clearly differentiated between the positive and the negative (Table 3 ). Component 1 represented positive traits with high loadings on good, pretty and inedible, while intelligent loaded highly on component 4 . Negative attitudes loaded highly on the second, the third and the fifth components. The most negative attitudes were held by respondents who ranked baboons as "similar to people". These respondents also ranked baboons within the top three as "bad". The third component represented people stating that baboons were edible. Finally, component 5 included individuals that rarely met baboons and that classified them as an "ugly" animal.

Gazelles were generally rated more often for positive features than for negative ones (Table 4). The first component suggested that, apart from the utilitarian perspective of edible, people attributed an aesthetic value to wildlife, "pretty", which was enhanced when the species could be used (eaten in this case). Only one cluster of respondents on component two exhibited negative attitudes towards the species;

\begin{tabular}{|l|c|c|c|c|}
\hline & \multicolumn{4}{|c|}{ Component } \\
\hline Total percent of variance explained & 1 & 2 & 3 & 4 \\
\hline Good & 15.1 & 14.7 & 13.8 & 13.4 \\
\hline Bad & .491 & .280 & .193 & -.377 \\
\hline Pretty & -.429 & -.392 & -.020 & .208 \\
\hline Ugly & .056 & -.038 & .135 & -.806 \\
\hline Intelligent & .072 & .081 & .391 & .649 \\
\hline Unintelligent & .669 & .042 & .148 & .142 \\
\hline Non-edible & -.743 & .185 & .290 & .039 \\
\hline Similar to people & -.134 & -.247 & .789 & .056 \\
\hline Frequently seen & .161 & .308 & .631 & -.043 \\
\hline Rarely seen & .132 & .641 & .163 & .227 \\
\hline
\end{tabular}

Table 2: Component matrix for perceptions of chimpanzees, after rotation (varimax). Rotation converged in 7 iterations (K-M-O $=0.53$ Bartlett's test of sphericity $\mathrm{X}^{2}=208.42, \mathrm{df}=45, \mathrm{P}<0.001$ ). For chimpanzees four main clusters of attitudes existed which explained $57 \%$ of the total variance in the attitudes that local people exhibited when responding to the wildlife photo. 


\begin{tabular}{|l|c|c|c|c|c|}
\hline & \multicolumn{5}{|c|}{ Component } \\
\hline $\begin{array}{l}\text { Total percent of variance } \\
\text { explained }\end{array}$ & $\mathbf{1}$ & $\mathbf{2}$ & $\mathbf{3}$ & $\mathbf{4}$ & $\mathbf{5}$ \\
\hline Good & 12.7 & 12.5 & 11.5 & 11.0 & 10.7 \\
\hline Bad & .793 & -.009 & -.025 & .031 & .136 \\
\hline Pretty & -.200 & .505 & -.290 & -.118 & .176 \\
\hline Ugly & .622 & -.037 & .314 & .034 & -.209 \\
\hline Intelligent & .003 & .220 & -.123 & -.102 & .699 \\
\hline Unintelligent & .071 & .211 & -.114 & .779 & -.212 \\
\hline Edible & .016 & .216 & -.143 & -.652 & -.229 \\
\hline Non-Edible & .121 & .132 & .788 & .005 & .063 \\
\hline Similar to people & .559 & .193 & -.546 & -.029 & .044 \\
\hline Frequently seen & .088 & .721 & .035 & .280 & .001 \\
\hline Rarely seen & .079 & .623 & .307 & -.257 & -.034 \\
\hline
\end{tabular}

Table 3: Component matrix for perceptions of baboons, after rotation (varimax). Rotation converged in 9 iterations (K-M-O $=0.519$, Bartlett's test of sphericity $\mathrm{X}^{2}=11.9, \mathrm{df}=55, \mathrm{p}<0.001$ ). There were five major components related to how people perceive baboons, explaining $58.4 \%$ of the total variance.

\begin{tabular}{|l|c|c|c|c|}
\hline & \multicolumn{4}{|c|}{ Component } \\
\hline Total percent of variance explained & 1 & 2 & 3 & 4 \\
\hline Good & 14.8 & 13.5 & 13.5 & 12.0 \\
\hline Bad & .687 & .122 & .032 & .105 \\
\hline Pretty & -.416 & .662 & -.264 & .059 \\
\hline Intelligent & .705 & .053 & -.111 & -.130 \\
\hline Unintelligent & .177 & .650 & .274 & -.076 \\
\hline Edible & -.180 & -.321 & .046 & -.039 \\
\hline Similar to people & .290 & .319 & .110 & .626 \\
\hline Frequently seen & -.185 & -.149 & -.055 & .774 \\
\hline Rarely seen & -.031 & .238 & .728 & -.139 \\
\hline
\end{tabular}

Table 4: Component matrix for perceptions of gazelles, after rotation (varimax). Rotation converged in 6 iterations (K-M-O $=0.542$, Bartlett's test of sphericity $\mathrm{X}^{2}=53.4, \mathrm{df}=36, \mathrm{P}=0.031$ ). For gazelles, five components explained $58.4 \%$ of variance observed across responses.

respondents who ranked "bad" highly for gazelles also tended to rank them as "intelligent". A third group ranked highly on frequent encounters with gazelles, though gazelles do not directly compete with people for resources which makes them hard to find nearby the farms. Finally, the fourth component identified people who see gazelles as similar to people and also edible.

Respondents' attitudes toward hyenas were generally negative and although more positive perceptions also emerged (Table 5). The first component had high loadings of hyenas as "bad" and "inedible". The second cluster of people was suggestive of more positive perceptions, with high loadings of "similar to people" and "pretty. The third group of people was those ranking hyenas highly as "unintelligent" and "ugly". The fourth component comprised people that perceived hyenas as "good", "ugly" and "less often seen". Finally, the fifth component consisted of high loadings by people who reported hyenas to be both "edible" and "pretty".

\section{Gender and religion: influences on perceptions}

Chimpanzees were ranked top as the animal respondents would like to be if they could no longer be humans $(n=76)$, and were the most frequently mentioned animal overall. Men seemed to be more interested in being a chimpanzee than women (Figure 1). Women showed a higher preference for gazelles. Figure 2 clearly indicated women's aversion to "being" chimpanzees. While some men also showed an aversion to being a chimpanzee as well, their choices seemed to be more evenly distributed than were women's.

Non-Muslims were less focused on primates and exhibited wider preferences (Figure 3). Chimpanzees were a species that most individuals, Muslim and non-Muslin would like NOT to be (Figure 4). Neither did Muslims feel any affinity for baboons. Apart from chimpanzees and baboons, they also rated snakes as species that they would not like to be. Non-Muslims singled out hyenas as one of the animals they would not like to be.

\section{Discussion}

Species appearance (aesthetic and biophilic), utility and behaviour clearly influenced people's sociozoologic classification of the four species in this study. Between four and five components emerged from the values applied to these species using simple descriptive adjectives. At least one component had loadings of adjectives that could be interpreted as indicating positive perceptions of all the species, even for the hyena. The aesthetic traits (good, pretty, not ugly, not bad) were attributed to chimpanzees (C5), baboons (C1), gazelle $(\mathrm{C} 1)$ and hyena (C4), while a utilitarian trait (edible) were seen for all but chimpanzees. Interestingly, traits that appear to reflect local knowledge of behaviour (intelligent, like humans, frequently seen) also loaded on components but not consistently across the species. Local knowledge may be confounded with judgements about

\begin{tabular}{|l|c|c|c|c|c|}
\hline & \multicolumn{5}{|c|}{ Component } \\
\hline $\begin{array}{l}\text { Total percent of } \\
\text { variance explained }\end{array}$ & $\mathbf{1}$ & $\mathbf{2}$ & $\mathbf{3}$ & $\mathbf{4}$ & $\mathbf{5}$ \\
\hline Good & 13.5 & 13.1 & 12.9 & 12.6 & 11.2 \\
\hline Bad & -.241 & -.080 & -.306 & .600 & .094 \\
\hline Pretty & .741 & -.165 & .068 & -.043 & .094 \\
\hline Ugly & .097 & .722 & -.058 & -.021 &. $\mathbf{4 2 0}$ \\
\hline Intelligent & .158 & -.115 &. $\mathbf{4 7 2}$ &. $\mathbf{5 4 5}$ & -.005 \\
\hline Unintelligent & .132 & -.031 & -.772 & .206 & -.105 \\
\hline Edible & .251 & .030 & .602 & .137 & -.107 \\
\hline Inedible & -.014 & .028 & .007 & -.022 & .925 \\
\hline Similar to people & .779 & .156 & .054 & .090 & -.095 \\
\hline Rarely Seen & -.077 & .838 & .070 & .009 & -.160 \\
\hline
\end{tabular}

Table 5: Component matrix for perceptions of hyenas, after rotation (varimax). Rotation converged in 6 iterations (K-M-O adequacy $=544$, Bartlet's test of sphericity $X^{2}=127, \mathrm{df}=45, \mathrm{P}<0.001$ ). Respondents' attitudes toward hyenas were organized in 5 main components explaining $63.2 \%$ of variance.

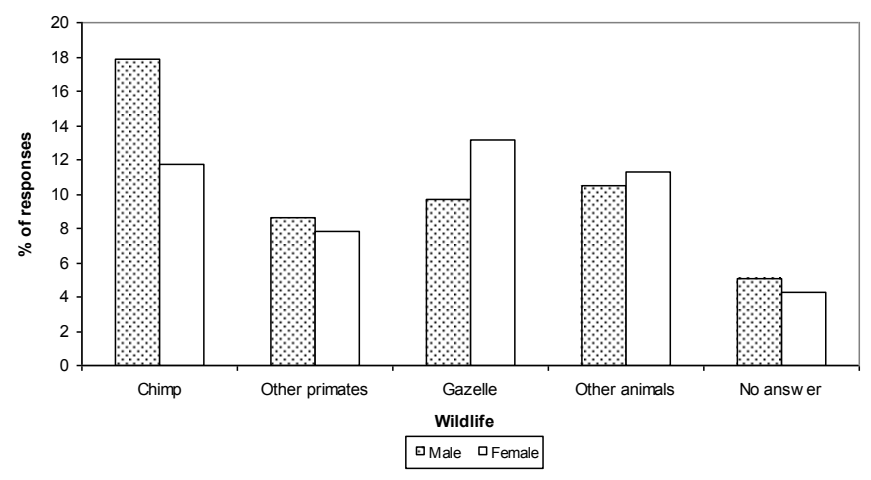

Figure 1: Nonhumans people would choose to be if they could not be humans by gender $(x 2=4.76, d f=4$, Cramer's $V=0.14, P>0.05)$. Men appeared to be more attached to general anthropomorphized features since they mainly chose primate species $(26.5 \%)$ instead of other animals. 


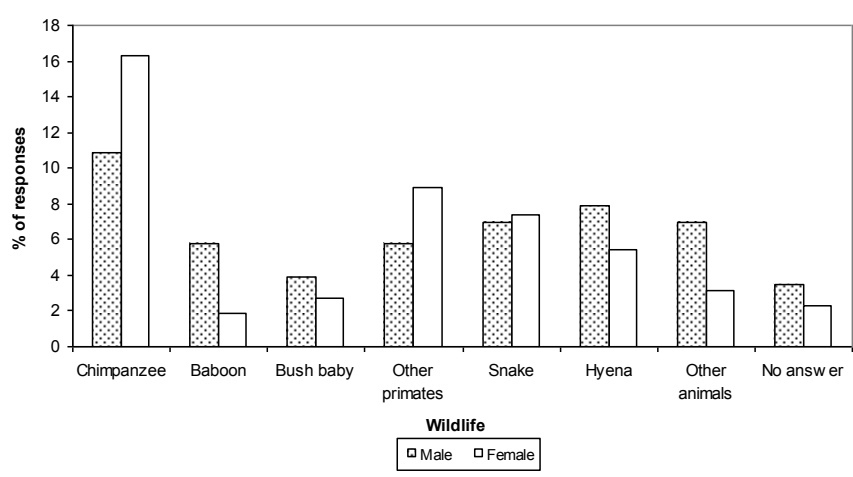

Figure 2: Nonhumans people would not choose to be if they could not be humans by gender $(X 2=15.25, \mathrm{df}=7$, Cramer's $\mathrm{V}=0.24, \mathrm{P}<0.05)$. This graph clearly indicated women's aversion to "being" chimpanzees.

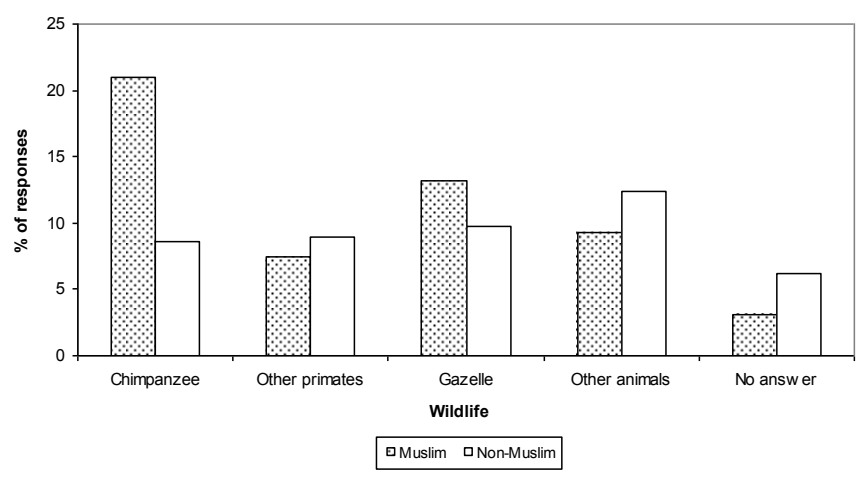

Figure 3: Nonhumans people would choose to be if they could not be humans by religion $(x 2=17.43, \mathrm{df}=4$, Cramer's $\mathrm{V}=0.26, \mathrm{P}<0.05)$. Muslims chose primates $(28.4 \%)$ in general and chimpanzees in particular as the top rated species that they would like to be.

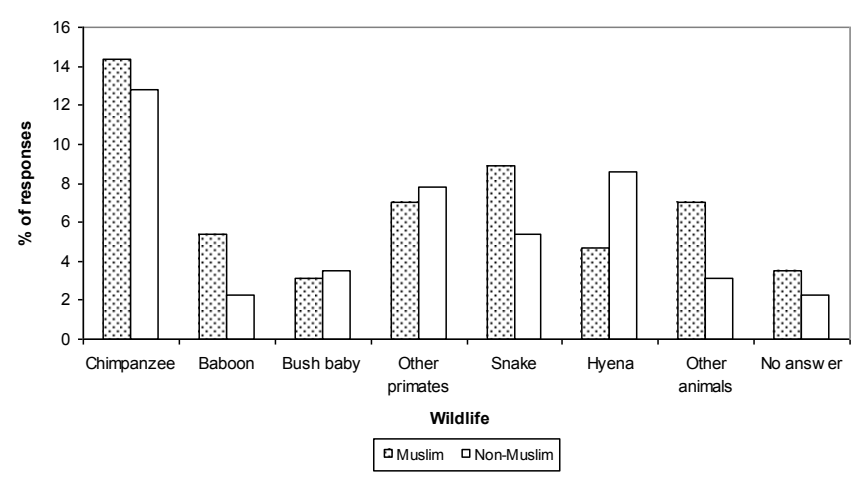

Figure 4: Nonhumans people would not choose to be if they could not be humans by religion $(X 2=11.53, d f=7$, Cramer's $V=0.21, P=0.01)$. Muslims rated chimpanzees slightly more often than non-Muslims.

intentions which were also being attributed to the species (e.g. intent to crop raid or to evade capture when being hunted). Further work to determine whether and how people attribute intention to species would be of interest in understanding how negative perceptions arise and how these affect the potential conservation status of the species (see for example: [56]). For example, among baboons, the high rating on ugly could represent fleeting glimpses or generalized fear which translated into an aesthetically negative perspective. Alternatively, respondents who referred to baboons as "similar to people", may have encountered baboons often and thus had many opportunities to assess their behaviour and activities possibly while these primates raided the villager's field.

Chimpanzees in this local context may not be a good model for a conservation "flagship" species. Encounter rate might be seen as negative since respondents who met these primates very often might be experiencing crop-raiding in their farms or be frightened when walking in the forest. On the other hand, being perceived as similar to humans might be a form of protection against hunting, and also made chimpanzees rate highly as inedible. Chimpanzees were also aesthetically ugly. Among Balanta people (non-Muslim), chimpanzees are viewed as ancestors that were punished by God due to their misbehaviour, and hence they are both ugly and "human", in addition to being inedible. However, even such potentially negative perceptions might assist in their conservation since the consumption of chimpanzee meat seems to be a taboo. On the other hand, the chimpanzee tendency to raid the farms makes them vulnerable to hostility from villagers. Most villagers grow subsistence crops along with some cash crops such as fruit essential for trading. Raiding species-especially primates-create negative perceptions, active hostility, lack of willingness to engage with conservation for these species, and even lethal acts (see for example: [57-63]). Chimpanzee raiding potentially puts them at risk of direct hostile action by farmers [64].

Edibility is a feature potentially open to misinterpretation. If a species is considered "edible", this suggests that its meat is desired and therefore sought-out. While some studies in North America and in Scandinavia suggest that hunting, game meat consumption and species conservation can co-exist [66], the long-term effects on populations remain highly equivocal even in well-policed societies $[67,68]$. Hunting and bushmeat consumption in Africa remain major threats to conservation and biodiversity programs $[7,68,69]$. As such, we interpret "edibility" as a conservation-negative feature, since it represents one of the hazards to the continued existence of species such as baboons and gazelles, as well as other nonhuman primates in this region [70].

From the outset of this research, we assumed that being perceived as similar to humans could act, per se, as a taboo regarding meat consumption. However, gazelles are clearly rated as both "similar to humans" and highly edible. It appears that edibility can also be associated with positive values-although not necessarily producing attitudes useful for conservation purposes.

The sociozoological scale in Tombali placed the most useful (edible) and least threatening species (gazelles) at its pinnacle. Hyenas potentially represented the most negative dimension for the sociozoologic scale. Legends about hyena misbehaviour may help to crystallize negative perceptions and according to traditional beliefs, hyenas are able to transform themselves into humans in order to hunt livestock and attack villagers; thus there is a taboo on their consumption by humans and despite being locally extinct, they remained negatively perceived.

\section{Conclusions}

A correlation between positive attitudes and edibility of wildlife was expected and consistently demonstrated. We suggest that despite being positive, this relationship might be problematic for species conservation in areas of high illegal bushmeat exploitation. In general, chimpanzees were perceived as "good animals", given their human-like 
affinities and appearance, but women were markedly negative about chimpanzees as were non-Muslim men. Chimpanzees in other areas are thought to attack women and children, often while they are protecting the farms. These situations seem to occur only sporadically, though attacks might be sufficiently serious to increase women's discomfort regarding this primate $[71,72]$. In the context of a conservation initiative that uses the local people's perspectives to harness enthusiasm for biodiversity protection, chimpanzees might not be a good flagship candidate. Women were less empowered to hold opinions and to profit from a conservation program, and they were more directly involved in conflict interactions with wildlife during their agricultural activities; they tended to hold negative perceptions of all species but gazelles. Religion influenced the degree of anthropocentrism, such that Muslims held more positive attitudes towards primates generally than did nonMuslims. Understanding how differences in belief structures, as well as those of power and gender, influence attitudes to wildlife should help harness the positive and manage the negative attitudes more effectively in a community based conservation program.

The Guinean sociozoologic scale of Cantanhez, clearly divides the species into "tame" good species (gazelles) and "hazardous" bad species (hyenas). At the midpoint, are primates, neither good nor bad. Their human-like appearance and behaviour can contribute to positive attitudes, while their crop-raiding makes them perceived of as pests. Chimpanzees-the conservation project's potential flagship species-were considered by these villagers as close relatives to humans; however, they may also be perceived as competitors for resources due to their raiding. Attitudes towards chimpanzees are uniformly ambivalent and thus its conservation status cannot be assured by local community based initiatives.

\section{Acknowledgements}

We thank A. Serangonha, A. Costa, R. Sá and S. Cumpón for helping with data collection. Thanks are also due to our sponsors: "Lanidor" and Foundation for Science and Technology [Ministry of Science, Tecnologia e Ensino Superior, Portugal (funding references: POCI/ANT/57434/2004 and SFRH/ BD/30351/2006)]. We would also like to acknowledge IBAP and AD-Guinea-Bissau-for all the logistic support provided. Finally, we want to thank all the people in Tombali who kindly and patiently collaborated in this research.

\section{References}

1. Ferraro PJ, Kramer RA (1997) Compensation and Economic Incentives: Reducing Pressure on Protected Areas. In: Kramer R and van Schaik C (eds), Last Stand - Protected areas and the defence of tropical biodiversity, Oxford University Press, New York, USA.

2. Wooddroffe R, Thirgood S, Rabinowitz A (2005) People and Wildlife: Conflict or Coexistence? Cambridge University Press, Cambridge, UK.

3. Walpole MJ, Thouless CR (2005) Increasing the Value of Wildlife Through NonConsumptive Use? Deconstructing the myths of ecotourism and communitybased tourism in the tropics. In: People and Wildlife: Conflict or Coexistence, Cambridge University Press, Cambridge, USA

4. Terborgh J, van Schaik C, Davenport L, Rao M (2002) Integrated Conservation and Development Projects: Problems and Potential. Making Parks Work, Island Press, Washington, USA.

5. Bandiaky S (2008) Gender Inequality in Malidino Biodiversity Community-based Reserve, Senegal: Political Parties and the 'Village Approach'. Conservation and Society 6: 62-73.

6. Davenport L, Brockelman WY, Wright PC, Ruf K, del Valle FBR (2002) Ecotourism Tools for Parks. In: Terborgh J, van Schaik C, Davenport $L$ and Rao M (Eds), Making Parks, Work Island Press, Washington, USA.

7. Hambler C, Canney SM (2004) Conservation, Cambridge University Press, Cambridge, UK.

8. Lee PC, Graham MD (2006) African elephants Loxodonta africana and humanelephant interactions: implications for conservation. International Zoo Yearbook 40: 9-19.
9. Siex SK, Strutisaker TT (1999) Colobus monkeys and coconuts: a study of perceived human-wildlife conflicts. J Appl Ecol 36: 1009-1020.

10. Strum SC (2010) The Development of Primate Raiding: Implications for Management and Conservation. Int J Primatol 31: 133-156.

11. Maisels F, Strindberg S, Blake S, Wittemyer G, Hart J, et al. (2013) Devastating decline of forest elephants in central Africa. PLoS One 8: e59469.

12. Wadley RL, Colfer CJP, Hood IG (1997) Hunting Primates and Managing Forests. The Case of Iban Farmers in West Kalimantan. Indonesia Human Ecology 25: 243- 271.

13. Carpareto GM, Fusari A (2000) Subsistence Hunting and Bushmeat Exploitation in Central-Western Tanzania, Biodiversity Conservation 9: 1571-1585.

14. Fa JE, Burn RW, Broad G (2002) Bushmeat Consumption and Preferences of Two Ethnic Groups in Bioko Island, West Africa, Human Ecology 30: 397- 416.

15. de Merode E, Homewood K, Cowlishaw G (2004) The value of bushmeat and other wild foods to rural households living in extreme poverty in Democratic Republic of Congo. Biological Conservation 118: 573-581.

16. Jones CB, Young J (2004) Hunting restraint by Creoles at the Community Baboon Sanctuary, Belize: a preliminary survey. J Appl Anim Welf Sci 7: 127141.

17. Bassett TJ (2005) Card-carrying hunters, rural poverty, and wildlife decline in northern Cote d'Ivoire. Geographical Journal 171:24-35.

18. De Merode E, Cowlishaw G (2006) Species protection, the changing informa economy, and the politics of access to the bushmeat trade in the Democratic Republic of Congo. Conserv Biol 20: 1262-1271.

19. Kellert SR, Heerwagen JH, Mador ML (2008) Biophilic Design: The Theory Science and Practice of Bringing Buildings to Life, Wiley Blackwell, New York USA.

20. Deth Jv, Scarbrough E (1995) The Impact of Values, Oxford University Press New York, USA.

21. Giddens A (2000) Sociology, Policy Press, Cambridge, UK.

22. Allport GW (1979) The Nature of Prejudice, Perseus Books, Massachusetts, USA.

23. Yzerbyt V, Leyens JP (2004) Psicologia Social, Edições 70, Lisbon.

24. Baron RA, Byrne DR, Branscombe NR (2007) Mastering Social Psychology, Pearson/Allyn and Bacon, Boston, USA.

25. Smith AM, Sutton SG (2008) The Role of a Flagship Species in the Formation of Conservation Intentions, Human Dimensions of Wildlife: 13: 127-140.

26. Giddens A, Duneier M, Appelbaum RP (2003) An ntroduction to Sociology W.W. Norton \& Co, London.

27. Arluke A, Sanders C (1996) Regarding Animals. Temple University Press Philadelphia, USA

28. Serpell J (1996) In the Company of Animals: A Study of Human-Animal Relationships, Cambridge University Press, Cambridge, UK.

29. Adams WM, Infield M (2001) Park Outreach and Gorilla Conservation: Mgahinga Gorilla National Park, Uganda. In: Hulme D, Murphree MW (Eds). African Wildlife and Livelihoods: The Promise and Performance of Community Conservation, James Currey, Oxford.

30. Adams WM, Infield M (2003) Who is on the Gorilla's payroll? Claims on Touris Revenue From a Ugandan National Park, World Development 31: 177-190.

31. Pais V (2005) Us and Them - Contribution to the study of the interaction between nonhuman primates and humans in regions of Administrative Quinara and Tombali - Republic of Guinea-Bissau BA Thesis, Technical University of Lisbon, Lisbon, Portugal.

32. Gilligham S, Lee PC (2003) People and Protected Areas: A study of loca perceptions of wildlife crop-damage conflict in an area bordering the Selous Game Reserve, Tanzania. 37: 316-325.

33. Jones SA (2006) A Political ecology of wildlife conservation in Africa. Review of African Political Economy 109: 483-495.

34. Rocha MTV (1997) Guinea: The Gentile Before the Portuguese Presence, University Portucalense, Oporto. 
Citation: Costa S, Casanova C, Sousa C, Lee P (2013) The Good, The Bad and The Ugly: Perceptions of Wildlife In Tombali (Guinea-Bissau, West Africa). J Primatol 2: 110. doi:10.4172/2167-6801.1000110

Page 7 of 7

35. Frazão-Moreira A (2001) As Classificações Botânicas Nalú (Guiné-Bissau): Consensos e Variabilidades, Etnográfica 5: 131-155.

36. Nóbrega A (2003) A Luta Pelo Poder na Guiné-Bissau. Instituto Superior de Ciências Sociais e Políticas, Lisboa.

37. Temudo M (2009) A Narrativa da Degradação Ambiental no Sul da GuinéBissau: uma desconstrução etnográfica, Etnográfica 13: 237-264.

38. Terborgh J, Peres C (2002) The Problem of People in Parks. In: Terborgh J, Schaik C von, Davenport L, Madhu R (eds). Making Parks Work, Island Press, Washington, USA.

39. Gippoliti S, Dell Omo G (1996) Primates of the Cantanhez Forest and the Cacine Basin, Guinea-Bissau, Orix 30: 74-80.

40. Gippoliti S, Dell'Omo G (2003) Primates of Guinea-Bissau, West Africa: Distribution and conservation status. Primate Conservation 19: 73-78.

41. Gippoliti S, Embalo DS, Sousa C (2003) Chimpanzee conservation status in Guinea-Bissau. In: Kormos R, Boesch C, Bakarr ML, Butynski T (Eds.) West African Chimpanzees: Status survey and conservation action plan, IUCN - The World Conservation Union, Cambridge, UK.

42. Twining $\mathrm{H}$, Arluke A, Patronek $\mathrm{G}$ (2000) Managing the Stigma of Outlaw Breeds: A Case Study of Pit Bull Owners. Society and Animals 8: 1-28.

43. Hill CM (1998) Conflicting attitudes towards elephants around the Budongo Forest Reserve, Uganda. Environmental Conservation 25: 244-250.

44. Mehta JN, Kellert SR (1998) Local attitudes toward community-based conservation policy and programmes in Nepal: a case study in the MakaluBarun Conservation Area. Environmental Conservation 25: 320-333.

45. Lee PC (2004) Who wins? Human-primate conflict in the context of conservation, development and gender. Primate Eye 84: 15-16.

46. Chambers R (2007) From PRA to PLA and Pluralism: Practice and Theory. Institute of Development Studies, London.

47. Moser A (2007) Gender and Indicators - Overview Report. United Nations Development Programme, USA

48. Noss RF (1990) Indicators for Monitoring Biodiversity- A hierarchical approach. Conservations Biology: 4: 355-364.

49. Andelman SJ, Fagan WF (2000) Umbrellas and flagships: efficient conservation surrogates or expensive mistakes? Proc Natl Acad Sci U S A 97: 5954-5959.

50. Osborn FV, Hill CM (2005) Techniques to Reduce Crop Loss: Human and technical dimensions in Africa. In: Wooddroffe R, Thirgood S, Rabinowitz A (Eds.), People and Wildlife: Conflict or Coexistence, Cambridge University Press, Cambridge, UK.

51. Hayes N (1998) Foundations of Psychology: an introductory text. (3rdedn), Thomas Nelson and Sons Ltd, London, UK.

52. Field A (2005) Discovering Statistics - Using SPSS. Sage Publications, London, UK.

53. Dancey CP, Reidy J (2007) Statistics without Maths for Psychology. Pearson, London, UK.

54. Fowler FJ (2002) Survey Research Methods. Sage Publications, Thousand Oaks, USA.

55. Douglas SP, Craig CS (2007) Collaborative and Iterative Translation: An

Citation: Costa S, Casanova C, Sousa C, Lee P (2013) The Good, The Bad and The Ugly: Perceptions of Wildlife In Tombali (Guinea-Bissau, West Africa). J Primatol 2: 110. doi:10.4172/2167-6801.1000110
Alternative Approach to Back Translation, Journal of International Marketing 15: $30-43$.

56. Jacobs MH, Vaske JJ, Roemer JM (2012) Toward a Mental Systems Approach to Human Relationships with Wildlife: The Role of Emotional Dispositions. Human Dimensions of Wildlife 17: 4-15.

57. Naugthon TL (1997) Farming the Forest Edge: Vulnerable Places and People around Kibale National Park, Uganda. Geographical Review 87: 27-46.

58. CM (2000) Conflict of Interest between People and Baboons: Crop-Raiding in Uganda. Int J Primatol 21: 299-316.

59. TL, Sicotte P, Paterson JD (2001) The conflict between vervet monkeys and farmers at the forest edge in Entebbe, Uganda. African Journal of Ecology 39 : 195-199.

60. Hill CM (2002) Primate Conservation and Local Communities-Ethical Issues and Debates. American Anthropologist 104: 1184-1194.

61. Kagoro RG (2004) Crop-raiding around Lake Mburo National Park, Uganda. African Journal of Ecology 42: 32-41.

62. Riley EP, Priston NE (2010) Macaques in farms and folklore: exploring the human-nonhuman primate interface in Sulawesi, Indonesia. Am J Primatol 72 848-854.

63. Wallace GE, Hill CM (2012) Crop damage by primates: quantifying the key parameters of crop-raiding events. PLoS One 7: e46636.

64. Fuentes A, Hockings KJ (2010) The ethnoprimatological approach in primatology. Am J Primatol 72: 841-847.

65. Brainerd SM, Kattenborn BK (2010) The Scandenavian Model: A different path to wildlife management. The Wildlife Professional 4: 3-7

66. Gordon IJ, Hester AJ, Festa BM (2004) The management of wild large herbivores to meet economic conservation and environmental objectives. $J$ Appl Ecol 41: 1012-1031.

67. Coltman DW, O’Donoghue P, Jorgenson JT, Hogg JT, Strobeck C, et al. (2003) Undesirable evolutionary consequences of trophy hunting. Nature 426: 655658.

68. Oates JF (2002) West Africa: Tropical Forest Parks on the Brink. In: Terborgh J, van Schaik C, Davenport L, Rao M (Eds). Making Parks Work 57-76, Island Press, Washington, USA

69. Rose AL (2002) Conservation must pursue human-nature biosynergy in the era of social chaos and bushmeat commerce. In: Fuentes A and Wolfe LD (Eds). Primates Face to Face - The Conservation Implications of Human-Nonhuman Primate Interconnections 208-239. Cambridge University Press, Cambridge UK.

70. Pailler S, Wagner JE, McPeak JG, Floyd DW (2009) Identifying Conservation Opportunities among Malinké Bushmeat Hunters of Guinea, West Africa. Human Ecology 37: 761-774.

71. Reynolds V (2005) The Chimpanzees of the Budongo Forest. Oxford University Press, New York, USA

72. Wooddroff R, Thirgood S, Rabinowitz A (2005) The Impact of Human-Wildlife Conflict on Natural Systems. People and Wildlife: Conflict or Coexistence? Cambridge University Press, Cambridge, UK.

Submit your next manuscript and get advantages of OMICS Group submissions

Unique features:

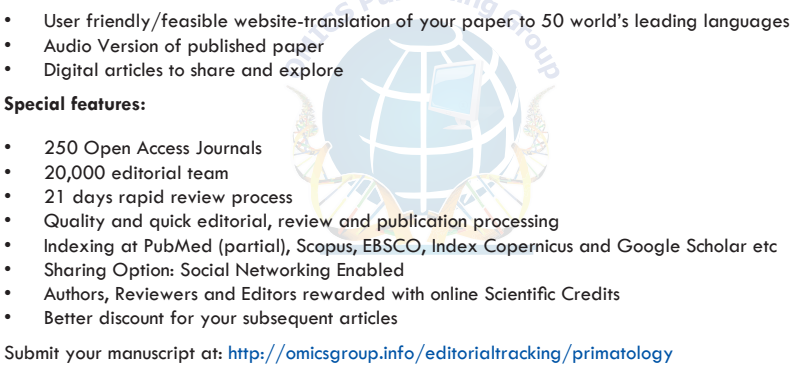

Submit your manuscript at: http://omicsgroup.info/editorialtracking/primatology 